\title{
GMR
}

Short Communication

\section{Evaluation of perfused bovine udder for gene expression studies in dairy cows}

\author{
I.S.B. Pinto ${ }^{1}$, I. Fonseca ${ }^{2}$, H.M. Brandão ${ }^{3}$, J.C. Gern ${ }^{3}$, A.S. Guimarães ${ }^{3}$, \\ W.A. Carvalho ${ }^{3}$, M.A.V.P. Brito ${ }^{3}$, L.F. Viccini ${ }^{1}$ and M.F. Martins ${ }^{3}$ \\ ${ }^{1}$ Universidade Federal de Juiz de Fora, Departamento de Biologia, \\ Instituto de Ciências Biológicas, Juiz de Fora, MG, Brasil \\ ${ }^{2}$ Instituto Federal Catarinense, Campus Videira, Videira, SC, Brasil \\ ${ }^{3}$ Embrapa Gado de Leite, Juiz de Fora, MG, Brasil \\ Corresponding author: M.F. Martins \\ E-mail: marta.martins@embrapa.br \\ Genet. Mol. Res. 16 (1): gmr16019637 \\ Received January 31, 2017 \\ Accepted March 3, 2017 \\ Published March 30, 2017 \\ DOI http://dx.doi.org/10.4238/gmr16019637
}

Copyright (C) 2017 The Authors. This is an open-access article distributed under the terms of the Creative Commons Attribution ShareAlike (CC BY-SA) 4.0 License.

\begin{abstract}
Intramammary infections are one of the main causes of productivity loss in dairy cows. To better understand the immune system response and to avoid the use of live animals, we validated the use of isolated bovine udder as an ex situ model. Six mammary glands were collected from cows ready for culling. Three udders were perfused with Tyrode's solution and three were not-perfused. During six hours, we collected perfusate samples for biochemical analysis. We also collected alveolar and teat canal tissue to evaluate gene expression. The biochemical parameters indicated that the perfused udders remained viable for the entire period of the experiment. A real-time polymerase chain reaction showed an increase in $18 \mathrm{~S} r R N A$ gene expression in the alveolar tissue at 3 and $4 \mathrm{~h}$ after perfusion. There was also an increase in the Ubiquitin gene in the teat canal from not-perfused udders at 1,3 , and $4 \mathrm{~h}$ after slaughter. In general, gene expression was stable
\end{abstract}

Genetics and Molecular Research 16 (1): gmr16019637 
during the experiment. Our results indicated that the isolated perfused bovine udder model is appropriate for genetic studies, opening a new perspective in animal experimentation methods.

Key words: Ex-situ model; Genes; Mammary gland

\section{INTRODUCTION}

Owing to ethical issues, the use of in vivo models represents an important barrier to be transposed in animal studies. Therefore, in vitro models are widely used as an alternative (Kietzmann et al., 1993). In Brazil, the National Council for Animal Experimentation Control - CONCEA - recognized 17 alternative methods for animal experimentation studies (Brasil, 2014). The validation of new methods is of great interest. One of these new methods, the isolated perfused bovine udder approach, has been used in studies of mammary gland metabolism (Massart-Leën et al., 1986; Ehinger et al., 2006) and cutaneous absorption of drugs and cosmetics (Bäumer and Kietzmann, 2001). Despite of its potential, the method has not been widely used to evaluate the response against pathogens. This approach would be highly relevant, especially considering gene expression, where various parameters can be measured over time without using live animals models. In particular, the use of the isolated perfused bovine udder approach would be advantageous to investigate the response of the immune system during the first hours after challenge by pathogens, which is essential to complement in vitro studies. The reduction of cost, the non-use of live animals, as well as the reduction of milk production loss and even animal sacrifice, represent other advantages of this method. Another advantage is the use of mammary glands collected from slaughterhouses that are discarded after hitting and have no commercial value. However, in this case, a rigorous control is needed regarding sample collection and the general conditions of the animals.

In this study, we evaluated an isolated perfused bovine udder method for gene expression studies by using dairy cows scheduled for culling. To this end, five constitutive genes were evaluated and biochemical parameters of the perfused udder were annotated.

\section{MATERIAL AND METHODS}

The experiment was approved by the Animal Ethics Committee of the Embrapa Dairy Cattle (license no. 11/2011). Six dairy cows without history of udder diseases were selected from the herd of Campo Experimental José Henrique Bruschi, located in Coronel Pacheco, Minas Gerais State, Brazil. These animals, with healthy mammary glands, were selected among others scheduled for culling. Before slaughter, the animals were submitted to a veterinary examination (performed by three professional veterinaries), for the clinical evaluation of the udder (palpation) and the strip cup test. At seven and three days before slaughter, as well as on the day of slaughter, 72 milk samples were collected in $50 \mathrm{~mL}$ sterile tubes. They were refrigerated and sent to the Milk Microbiology Laboratory of Embrapa Dairy Cattle, located in Juiz de Fora, Minas Gerais, Brazil, for microbiological tests.

The udders were refrigerated at $8^{\circ} \mathrm{C}$ immediately after collection and transported in isothermal boxes to the Laboratory of Nanotechnology for Animal Health and Production of Embrapa Dairy Cattle. There, they were fixed, in the natural position, to a metal frame, using the proximally inserting skin and suspensory ligament. The time between collection and

Genetics and Molecular Research 16 (1): gmr16019637 
perfusion of the udder in the laboratory was $40 \mathrm{~min}$. The experiment was designed as described by Kietzmann et al. (1993) and Ehinger and Kietzmann (2000), using a perfusion fluid temperature of $37^{\circ} \mathrm{C}$. For the viability tests, three udders were perfused with Tyrode's solution $\left(\mathrm{NaCl} 137 \mathrm{mM} ; \mathrm{KCl} 2.7 \mathrm{mM} ; \mathrm{CaCl}_{2} \cdot 2 \mathrm{H}_{2} \mathrm{O} 1.36 \mathrm{mM} ; \mathrm{MgCl}_{2} \cdot 6 \mathrm{H}_{2} \mathrm{O} 0.50 \mathrm{mM} ; \mathrm{NaH}_{2} \mathrm{PO}_{4} \cdot \mathrm{H}_{2} \mathrm{O}\right.$ $0.36 \mathrm{mM} ; \mathrm{NaHCO}_{3} 11.90 \mathrm{mM}$; Glucose $5.50 \mathrm{mM}$ ). The remaining three udders were placed without supply of oxygen or nutrients (not-perfused) during the experimental period.

Tissue samples were taken from the six udders (120 alveolar tissue samples and 120 teat canal samples). For the gene expression analyses, samples were collected from the four quarters of each udder at $0,1,3,4$, and $6 \mathrm{~h}$ after slaughter. The lactate dehydrogenase (LDH) activity and lactate production were also measured in the perfusate samples at 0 and $6 \mathrm{~h}$ after perfusion, to provide an indication of the conservation and oxygenation of the tissues (Kietzmann et al., 1993). These samples were stored at $-20^{\circ} \mathrm{C}$ and sent to a commercial laboratory for analysis.

Total RNA was extracted using the RNeasy Mini Kit (Qiagen, Valencia, CA, USA) following the manufacturer instructions. The total RNA isolated was quantified by spectrophotometry (NanoDrop Technologies, Wilmington, DE, USA). RNA quality was assessed by the RNA Integrity Number (RIN) after analysis on a Bioanalyzer 2100 (Agilent, Palo Alto, CA, USA) and eight samples were discarded due to RNA degradation (RIN values below 5.0). First cDNA strand was synthesized using the SuperScript III First-Strand Synthesis System for RT-PCR kit (Invitrogen, Carlsbad, CA, USA) and the cDNA was stored at $-20^{\circ} \mathrm{C}$ until the real-time polymerase chain reaction (PCR).

Since gene expression can be affected by external stimuli, such as an absence of oxygen and nutrients (Siqueira, 2009), we choose the main endogenous control genes described in the literature to validate the stability of the udder when subjected to perfusion. Among those, there are genes related to synthesis, degradation, and transport of proteins, such as Ubiquitin, RPLPO (ribosomal protein, large, P0), HPRT (hypoxanthine-guanine phosphoribosyltransferase) and 18S rRNA (Hochstrasser, 2009), in addition to others related to the transport of electrons and the respiratory chain, such as the GAPDH (glyceraldehyde 3-phosphate dehydrogenase) gene (Nicholls et al., 2012).

Expression was compared to Ubiquitin, $18 S$ rRNA, HPRT, GAPDH and RPLP0 genes in the tissue samples collected from the six bovine udders totaling 232 samples. The real-time PCR was carried out using the SYBR Green ${ }^{\circledR}$ PCR Master Mix (Applied Biosystems, Foster City, CA, USA), according to the manufacturer recommendations, optimizing the conditions for each primer (Table 1). After 40 amplification cycles, the dissociation curve was plotted to assure that each reaction produced a single fragment.

Table 1. Concentrations used of cDNA and primer for each gene and tissues evaluated.

\begin{tabular}{l|l|c|c|l}
\hline Tissue & Gene & Primer (nM) & cDNA (ng) & Reference \\
\hline \multirow{5}{*}{ Alveolar tissue } & $18 S$ rRNA & 600 & 100 & Wang et al., 2005 \\
\cline { 2 - 5 } & GAPDH & 100 & 100 & Mount et al., 2009 \\
\cline { 2 - 5 } & HPRT & 300 & 100 & Tao et al., 2004 \\
\cline { 2 - 5 } & RPLP0 & 200 & 100 & Mount et al., 2009 \\
\cline { 2 - 5 } & Ubiquitin & 150 & 100 & Singh et al., 2008 \\
\hline \multirow{5}{*}{ Teat canal } & $18 S$ rRNA & 600 & 200 & Wang et al., 2005 \\
\cline { 2 - 5 } & GAPDH & 100 & 200 & Mount et al., 2009 \\
\cline { 2 - 5 } & HPRT & 50 & 200 & Tao et al., 2004 \\
\cline { 2 - 5 } & RPLP0 & 200 & 200 & Mount et al., 2009 \\
\cline { 2 - 5 } & Ubiquitin & 200 & 200 & Singh et al., 2008 \\
\hline
\end{tabular}

Genetics and Molecular Research 16 (1): gmr16019637 
The data from the real-time PCR runs, generated by the ABI Prism 7300 Sequence Detection Systems, were exported to Excel files for analysis. The coefficient of variation between duplicates was calculated and those with values above $5 \%$ were repeated.

The efficiency of the reactions was calculated using REST $^{\circ}$ 2009, developed by Pfaffl et al. (2002) and Qiagen (available at http://www.gene-quantification.de/rest-2009.html). The expression stability of the five genes was evaluated using geNorm software (Vandesompele et al., 2002). Two out of five genes with the lowest expression variability and the greatest stability $(R P L P 0=0.064$ and HPRT $=0.067)$ for each analyzed tissue were selected as endogenous references to normalize the results.

Glucose and lactate concentration and LDH activity from the perfusate samples were analyzed with paired t-tests using SAS (SAS Institute Inc., 2008). The real-time PCR data were analyzed using REST $^{\circ} 2009$, to compare the gene expression levels.

None of the animals had clinical mastitis and no clots were observed in milk samples analyzed by the strip cup test. However, 15 milk samples were contaminated with Corynebacterium sp. (data not shown). Although these microorganisms can affect the viability of the glands, the samples were not discarded in advance because this microbe is a secondary pathogen that is often present in the mammary glands of lactating cows (Gonçalves et al., 2014).

To check the viability of the three perfused udders, we measured the concentrations of glucose and lactate, and LDH activity. The samples were collected at the start $(0 \mathrm{~h})$ and end $(6$ h) of the experiment and the udders were considered viable if these three parameters remained relatively constant. The difference in the concentrations of glucose ( $0 \mathrm{~h}: 243 \pm 37.65 ; 6 \mathrm{h:} 250 \pm$ $57.53)$ and lactate $(0 \mathrm{~h}: 38.7 \pm 13.59 ; 6 \mathrm{~h}: 30.56 \pm 18.83)$, and LDH activity $(0 \mathrm{~h}: 18.33 \pm 23.15$; $6 \mathrm{~h}: 41.67 \pm 29.17)$ were not significant $(\mathrm{P}<0.05)$ suggesting that the perfused udders were in stable conditions. These data also demonstrated that the contamination by Corynebacterium sp. did not affect the viability of the perfused udders during the evaluated interval.

The HPRT and RPLPO genes were selected as endogenous references to normalize the data once they showed the lowest expression variability both in the alveolar and teat canal tissues. The expression levels of Ubiquitin, GAPDH, and $18 S \mathrm{SRNA}$ were analyzed in two kinds of tissue from the perfused (P) and not-perfused (NP) glands, comparing the observed values at $1,3,4$, and $6 \mathrm{~h}$ after perfusion.

\section{RESULTS AND DISCUSSION}

In the alveolar tissue samples, we noted that, compared to at $0 \mathrm{~h}$, the expression of $18 \mathrm{~S}$ $r R N A$ showed a near three-fold increase at 4 and $6 \mathrm{~h}(\mathrm{P}<0.05$, Figure $1 \mathrm{~A})$ in the perfused udders. This increase in gene expression might indicate that cell activity remained constant during the perfusion period, enabling continued RNA transcription and protein synthesis (Hayashi et al., 2012). This result can be explained by an increase in the number of ribosomes. It is also possible that nutrients remaining in the milk ducts and inside the glands could have maintained a stable cell activity that did not significantly affect gene function during the experimental period. Another reason that could explain the high viability of this tissue is the direct arrival of the Tyrode solution through the main artery used for perfusion. This may have more efficiently maintained the osmolarity and temperature, and hence the local cell activity. Therefore, this result is an indication that the alveolar tissue can remain stable for at least $6 \mathrm{~h}$, the maximum time evaluated during this experiment. There was an increase in expression of GAPDH and Ubiquitin in the perfused udder samples during the experiment. However, compared to notperfused udder samples, the difference was not statistically significant (Figures 1B and 1C).

Genetics and Molecular Research 16 (1): gmr16019637 

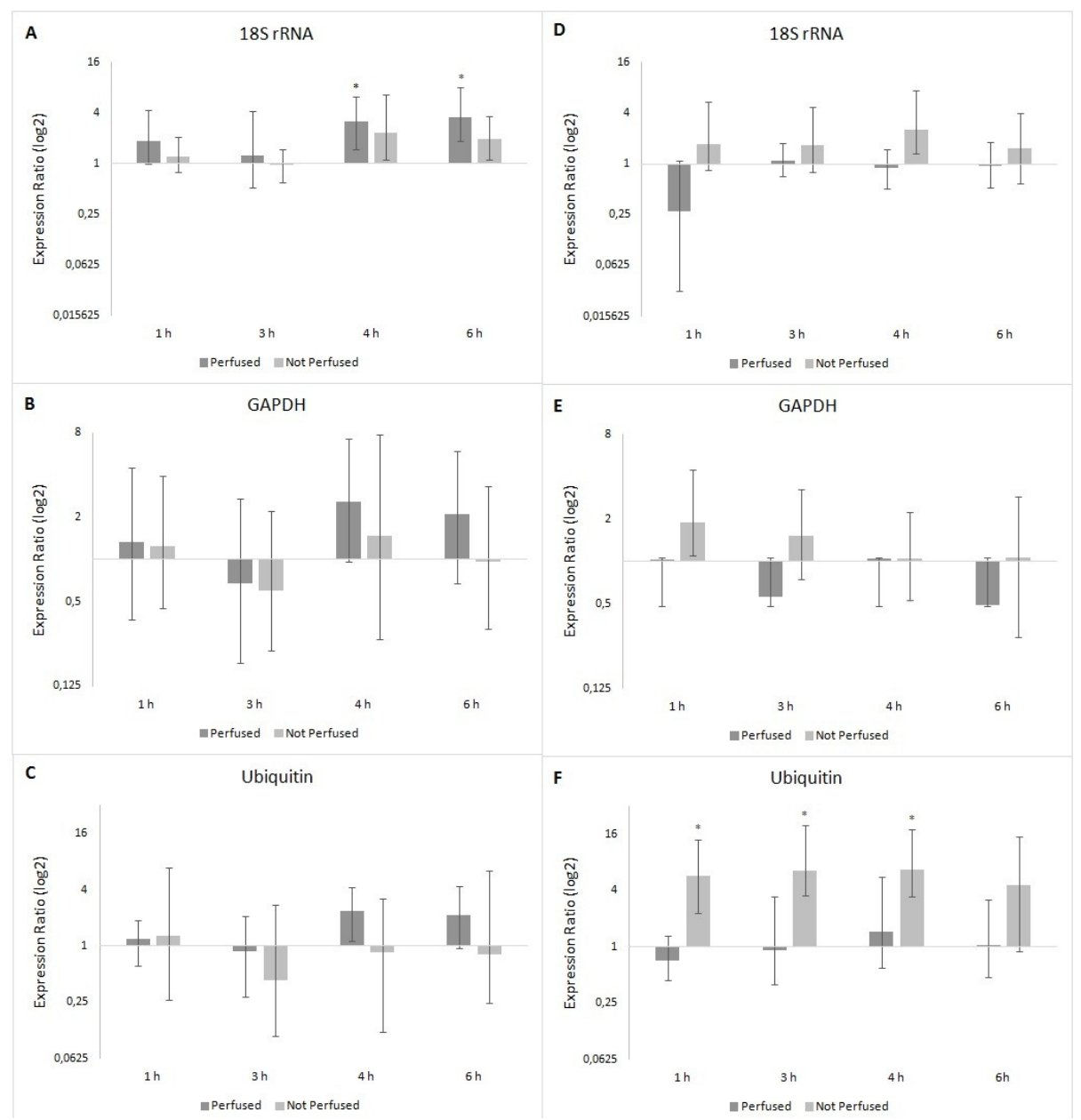

Figure 1. Expression levels of $18 S \mathrm{r} R N A, G A P D H$, and Ubiquitin genes in perfused and not-perfused udders evaluated at $1,3,4$, and $6 \mathrm{~h}$, using $0 \mathrm{~h}$ as a reference. A-C: alveolar tissue, $\mathbf{D}-\mathbf{F}$ : teat canal tissue $(* \mathrm{P}<0.05)$.

In the teat canal samples, the expression of Ubiquitin increased at 1,3 , and $4 \mathrm{~h}$ in the not-perfused udders (Figure 1F), while the variation in expression of 18S rRNA and GAPDH were not significantly different (Figures 1D and 1E). The alterations in Ubiquitin expression might indicate a cell cycle deregulation associated with the necroptosis process (Iwai et al., 2014). The teat canal needs its basic physiological functions, such as peripheral circulation, to be active and maintain osmolarity. Therefore, the arrival of nutrients and tissue oxygenation may have contributed to this tissue being more sensitive to gene expression.

In general, in the not-perfused udders, the absence of oxygen seems to have changed the basal functions of the analyzed genes causing expression-level changes. In the perfused udders, these functions were maintained, indicating the viability of the perfusion model to keep the glands in physiological good condition. We also observed that the perfusion response was different for each tissue and therefore, it is important to evaluate each one separately to validate gene expression. 
Our results suggest that the isolated perfused bovine udder model is appropriate for gene expression studies in alveolar tissue, since, in general, the evaluated samples showed stability for the constitutive genes. Thus, it can be concluded that the isolated perfused bovine udder may be a suitable model for genetic studies of the initial response to chemical and infectious agents, avoiding the use and possible impairment of the welfare of producing animals.

\section{Conflicts of interest}

The authors declare no conflict of interest.

\section{ACKNOWLEDGMENTS}

Research financially supported by CNPq (\#473414/2011-2) and FAPEMIG (CVZ PPM \#00075-13). We are grateful to the technicians of the Campo Experimental José Henrique Bruschi (Embrapa Dairy Cattle) for the selection and slaughter of the animals and the collection of milk samples. I.S.B. Pinto has a CAPES scholarship, I. Fonseca, L.F. Viccini, and M.F. Martins have a CNPq scholarship.

\section{REFERENCES}

Bäumer W and Kietzmann M (2001). Effects of steroidal and non-steroidal antiphlogistic drugs on eicosanoid synthesis in irritated skin: studies with the isolated perfused bovine udder. J. Pharm. Pharmacol. 53: 743-747. http://dx.doi. org/10.1211/0022357011775875

Brasil (2014). Resolução Normativa nº 18, de 24 de setembro de 2014. http://www.mct.gov.br/upd_blob/0234/234796.pdf Acessed February $28^{\text {th }}, 2017$.

Ehinger AM and Kietzmann M (2000). Tissue distribution of oxacillin and ampicillin in the isolated perfused bovine udder. J. Vet. Med. A Physiol. Pathol. Clin. Med. 47: 157-168. http://dx.doi.org/10.1046/j.1439-0442.2000.00272.x

Ehinger AM, Schmidt H and Kietzmann M (2006). Tissue distribution of cefquinome after intramammary and "systemic" administration in the isolated perfused bovine udder. Vet. J. 172: 147-153. http://dx.doi.org/10.1016/j.tvj1.2005.02.029

Gonçalves JL, Tomazi T, Barreiro JR, Braga PA, et al. (2014). Identification of Corynebacterium spp. isolated from bovine intramammary infections by matrix-assisted laser desorption ionization-time of flight mass spectrometry. Vet. Microbiol. 173: 147-151. http://dx.doi.org/10.1016/j.vetmic.2014.06.028

Hayashi R, Hayashi S, Arai K, Chikuda M, et al. (2012). Effects of antioxidant supplementation on mRNA expression of glucose-6-phosphate dehydrogenase, $\beta$-actin and 18S rRNA in the anterior capsule of the lens in cataract patients. Exp. Eye Res. 96: 48-54. http://dx.doi.org/10.1016/j.exer.2012.01.001

Hochstrasser M (2009). Origin and function of ubiquitin-like proteins. Nature 458: 422-429. http://dx.doi.org/10.1038/ nature 07958

Iwai K, Fujita H and Sasaki Y (2014). Linear ubiquitin chains: NF-кB signalling, cell death and beyond. Nat. Rev. Mol. Cell Biol. 15: 503-508. http://dx.doi.org/10.1038/nrm3836

Kietzmann M, Löscher W, Arens D, Maass P, et al. (1993). The isolated perfused bovine udder as an in vitro model of percutaneous drug absorption. Skin viability and percutaneous absorption of dexamethasone, benzoyl peroxide, and etofenamate. J. Pharmacol. Toxicol. Methods 30: 75-84. http://dx.doi.org/10.1016/1056-8719(93)90010-C

Massart-Leën AM, Peeters G, Vandeputte-Van Messom G, Roets E, et al. (1986). Effects of valerate and isobutyrate on fatty acid secretion by the isolated perfused mammary gland of the lactating goat. Reprod. Nutr. Dev. 26: 801-814. http://dx.doi.org/10.1051/rnd:19860505

Mount JA, Karrow NA, Caswell JL, Boermans HJ, et al. (2009). Assessment of bovine mammary chemokine gene expression in response to lipopolysaccharide, lipotechoic acid + peptidoglycan, and CpG oligodeoxynucleotide 2135. Can. J. Vet. Res. 73: 49-57.

Nicholls C, Li H and Liu JP (2012). GAPDH: a common enzyme with uncommon functions. Clin. Exp. Pharmacol. Physiol. 39: 674-679. http://dx.doi.org/10.1111/j.1440-1681.2011.05599.x

Pfaffl MW, Horgan GW and Dempfle L (2002). Relative expression software tool (REST) for group-wise comparison

Genetics and Molecular Research 16 (1): gmr16019637 
and statistical analysis of relative expression results in real-time PCR. Nucleic Acids Res. 30: e36. http://dx.doi. org/10.1093/nar/30.9.e36

SAS Institute Inc (2008). SAS/STAT ${ }^{\circledR} 9.2$ User's guide. SAS Institute Inc, Cary.

Singh K, Davis SR, Dobson JM, Molenaar AJ, et al. (2008). cDNA microarray analysis reveals that antioxidant and immune genes are upregulated during involution of the bovine mammary gland. J. Dairy Sci. 91: 2236-2246. http:// dx.doi.org/10.3168/jds.2007-0900

Siqueira DM (2009). Estudo da correlação entre a expressão de genes reguladores do estado de hipóxia e a intensidade da resposta inflamatória aguda. Master's dissertation, Universidade de São Paulo. São Paulo. http://www.teses.usp.br/ teses/disponiveis/42/42133/tde-07072009-114219/pt-br.php.

Tao W, Mallard B, Karrow N and Bridle B (2004). Construction and application of a bovine immune-endocrine cDNA microarray. Vet. Immunol. Immunopathol. 101: 1-17. http://dx.doi.org/10.1016/j.vetimm.2003.10.011

Vandesompele J, De Preter K, Pattyn F, Poppe B, et al. (2002). Accurate normalization of real-time quantitative RT-PCR data by geometric averaging of multiple internal control genes. Genome Biol. 3: RESEARCH0034.

Wang YH, Byrne KA, Reverter A, Harper GS, et al. (2005). Transcriptional profiling of skeletal muscle tissue from two breeds of cattle. Mamm. Genome 16: 201-210. http://dx.doi.org/10.1007/s00335-004-2419-8

Genetics and Molecular Research 16 (1): gmr16019637 